http://jmscr.igmpublication.org/home/ ISSN (e)-2347-176x ISSN (p) 2455-0450 crossref DOI: https://dx.doi.org/10.18535/jmscr/v8i2.95

\title{
A Comparative study of Tuberculosis MDR Cases in HIV and non -HIV Person of Coal field area of Dhanbad
}

\author{
Authors \\ Dr Sujeet Kumar Tiwary ${ }^{1}$, Dr Binay Kumar Singh ${ }^{2 *}$, Dr Sunil Kumar Sinha ${ }^{3}$, \\ Rupesh Kumar ${ }^{4}$, Dr Ajay Kumar ${ }^{5}$ \\ ${ }^{1}$ Tutor, Dept. of Microbiology, PMCH Dhanbad \\ ${ }^{2}$ H.O.D \& Associate Professor, Dept. of Microbiology, PMCH, Dhanbad \\ ${ }^{3}$ M.O. Cum- Assistant .Professor, Community Medicine PMCH, Dhanbad \\ ${ }^{4}$ Consultant Microbiologist RNTCP, IRL Itaki Ranchi, Jharkhand \\ ${ }^{5}$ Professor, Dept. of Pathology, PMCH Dhanbad, Cum- Blood Bank in - Charge PMCH \\ *Corresponding Author \\ Dr Binay Kumar Singh
}

\begin{abstract}
The HIV and Tuberculosis is one of the major health challenges in the present time. Many people's suffering co-infection with HIV and tuberculosis in Jharkhand and other state of India. Mycobacterium tuberculosis is the most common cause of Tuberculosis because of airborne transmission mode ${ }^{\{1,2\}}$ HIV may be transmitted through sexual intercourse and certain body fluids that are capable of containing high concentration of HIV. These fluids included blood semen, vaginal and rectal secretions. HIV weakens the immune system and increase the risk of $T B{ }^{\{3\}\}} \cdot H I V$ with $T B$ is called HIV /TB co-infection ${ }^{\{3,4\}}$. This study will focus on HIV/TB co-infection having Multi drug resistant tuberculosis. ${ }^{\{4,\}}$ this study is done with the name, address, and any other contacts of the Person will be kept secret.

Materials and Methods: All Study was done at the department of Microbiology PMCH Dhanbad from December 2018 to December 2019 with the help of RNTCP Designated Microscopy centers (DMC) and Integrated Counseling and Testing center (ICTC) at PMCH Dhanbad. All 262 blood and sputum samples were collected in the (Designated Microscopy Centre) RNTCP and Integrated Counseling and Testing center at Patliputra Medical college and hospital. All blood / sputum samples were sent to the Central Research laboratory PMCH Dhanbad.

Result: In our study we have found that the Tuberculosis infection is much higher than for HIV. In this study we have found the HIV/TB co infected Patients Rifampicin drug resistant percentage is higher than for Isoniazid drug. This investigation non-infection HIV patients and co-infected HIV/TB patients Isoniazid less resistant than Rifampicin.

Keywords: Rifampicin, Isoniazid, Fluorescence Microscopy, MGIT, Multi drug Resistant.
\end{abstract}

\section{Introduction}

Tuberculosis and HIV are global public health problem. TB has been identified as one of the leading cause of death among HIV-infected persons .People living with HIV infected with Mycobacterium Tuberculosis are at 25 times greater risk of developing TB compared with HIV non- infected-person. ${ }^{\{5\}}$ On average, $0.6 \%$ of the 
TB patients were infected both with HIV and MDR- TB. According to(WHO). ${ }^{\{6,7\}}$ Tuberculosis is one of the most common infection in HIV immune compromised Patients leading to death of co-infected Patients. ${ }^{\{8,9\}}$ These disease coinfection HIV drives a decline in immunity while tuberculosis progresses due to defective immune status ${ }^{\cdot(9,10\}}$ This condition becomes more severe in case of any stage of HIV infection. ${ }^{\{11,12\}}$ This study Helps to identified HIV/TB co-infection Multi drug resistant tuberculosis in the coal field area of Dhanbad district of Jharkhand. In our study we have used HIV/Tb suspected Samples and which includes some HIV reactive patients through help of ICTC and RNTCP.

\section{Materials and Methods}

All Study was done at the department of Microbiology PMCH Dhanbad from December 2018 to December 2019 with the help of RNTCP Designated Microscopy centers (DMC) and Integrated Counseling and Testing center (ICTC) at the PMCH Dhanbad. All of 262 suspected blood and sputum samples were collected in the (Designated Microscopy Centre) RNTCP and Integrated Counseling and Testing center at Patliputra Medical college and hospital. All blood / sputum samples were sent to the Central Research laboratory PMCH Dhanbad.

Sample collection Procedure: The samples collection will follow the procedure of Revised National Tuberculosis Control program (RNTCP). The diagnosis of pulmonary tuberculosis is primarily sputum based in accordance with the WHO guidelines. All Sputum samples were collected by the use of large Mouthed screw capped leak proof $50 \mathrm{ml}$ plastic container. All Blood samples were collected under NACO guideline by using sterilized $3 \mathrm{ml}$ syringe and $5 \mathrm{ml}$ vial.In our study we have used HIV/TB suspected Blood/Sputum Samples and which include some HIV reactive patients through the help of ICTC and DMC with the name, address, and any other contacts of the Person will be kept secret.
Sputum Microscopy: Sputum Microscopy examination done by using Fluorescence microscopy Method.

Mycobacteria Growth Indicator Tube: Mycobacterium Growth indicator tube is used for the detection of Mycobacterium Tuberculosis. The Complete Medium with OADC enrichment and PANTA antibiotics mixture.

\section{Identification of Multidrug Resistant}

Tuberculosis: In Mycobacterium growth indicator tube tuberculosis bacteria will grows in the presence of tuberculosis drugs. If then bacteria grows then they are resistant to the drugs. Drugs could not stop their growth.

HIV Test and confirmatory Test: If the combs test is reactive then confirmation is done by

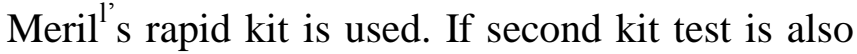
reactive then $3^{\text {rd }}$ Aids scan kit is used for conformation According to NACO guidelines.

Age and Sex Predilection of HIV/TB: In this study all patients of both genders who were more than 18 years of age and Suspected of having HIV and Tuberculosis were included.

Statistical Analysis: All Data were analyzed with standard statistical method, percentage were computed for all variables results were presented in the form of table and column.

\section{Result}

In our study we have used HIV/TB suspected Blood/Sputum Samples and which include some HIV reactive patients through the help of ICTC and DMCwith the name, address, and any other contacts of the Person will be kept secret. In this study a total number of 262 suspected blood samples of HIV and total 262 suspected Sputum samples were collected and investigate by the microbiology standard procedure in the department of Microbiology of the Patliputra Medical Collage and Hospital Dhanbad. In this study we Found that the total number of male patients were $163(62 \%)$ and the total numbers of female patients were 99 (38\%) According to (Table 1). In our study total numbers of Positive Sputum samples $115(44 \%)$ and total numbers of 
negative Sputum samples 147 (56\%), overall total Sputum samples 262 (According to Table 2.). The total number of HIV reactive Blood Samples $87(33 \%)$ and the total number of HIV nonreactive Blood samples $175(67 \%)$ overall total Blood samples is 262 (According to Table 3.). We have found this Tuberculosis (44\%) infection is much more higher than for HIV $33 \%$. According (Table 2 \& 3). After Our investigation we have found that a total number of 87 blood samples is HIV reactive and done Fluorescence Microscopy examination of a total numbers of 31 (36\%) samples is sputum positive (approx. 36\%) positive and a total number of negative samples is 56 (approx. 64\%). We have examined approximately 87 blood HIV Reactive samples 31
Patients samples were Both HIV reactive and Sputum Positive. (According to Table No-4.). In our investigation we have found that Total Number of Non HIV infected TB Patients is 31. Out of 31 HIV Reactive Patients 6 (19\%) Patients were Rifampicin resistant and 4 (12\%) Patients were Isoniazid resistant. Out of $31 \mathrm{HIV} / \mathrm{TB} \mathrm{Co}-$ infected Patients 3 (9.6\%) patients we are found Multi Drug resistant. (According to Table No5.). In our last table (No-6), in our study we have found that total Number of Non HIV infected TB Patients is 175.Out of which 25 (14\%) Patients Sputum Samples is Rifampicin resistant and 16 (9.1\%) Sputum Samples Isoniazid resistant. We have also found Multi Drug Resistant is 4 (2.2\%) out of 175. (According to Table No 6.).

Table- 1 Sex wise distribution among total blood \& Sputum Samples

\begin{tabular}{|l|l|c|c|c|c|}
\hline \multicolumn{2}{|c|}{ Total Numbers of Samples. } & \multicolumn{4}{|c|}{ Gender } \\
\cline { 3 - 6 } \multicolumn{2}{c|}{} & Male & Total (\%). & Female. & Total (\%). \\
\hline Blood & 262 & 163 & 62.2 & 99 & 38 \\
\hline Sputum & 262 & 163 & 62.2 & 99 & 38 \\
\hline
\end{tabular}

Table.2 Fluorescence Microscopy Total No. of Positive and Negative samples \& \%

\begin{tabular}{|l|c|c|c|c|}
\hline $\begin{array}{l}\text { Total Numbers of } \\
\text { Sputum Samples. }\end{array}$ & \multicolumn{4}{|c|}{ Fluorescence Microscopy (Mycobacterium Tuberculosis). } \\
\hline 262 & Total No of Positive samples. & $\begin{array}{c}\text { Total } \\
(\%)\end{array}$ & $\begin{array}{c}\text { Total No of Negative } \\
\text { Samples. }\end{array}$ & Total (\%) \\
\cline { 2 - 5 } & 115 & $44 \%$ & 147 & $56 \%$ \\
\hline
\end{tabular}

Table.3 Total No of blood samples HIV Reactive and Non-Reactive with $\%$.

\begin{tabular}{|c|c|c|c|c|c|c|c|c|c|}
\hline \multirow{3}{*}{$\begin{array}{l}\text { Total } \\
\text { of }\end{array} \begin{array}{l}\text { Blood } \\
\text { samples. }\end{array}$} & \multicolumn{3}{|c|}{$\begin{array}{c}1^{\text {st }} \\
\text { HIV test }\end{array}$} & \multirow{2}{*}{\multicolumn{2}{|c|}{$\begin{array}{c}2^{2^{\text {nd }}} \text { Confirmatory } \\
\text { Test } \\
\text { Merils Rapid } \\
\text { Kit Test. }\end{array}$}} & \multirow{2}{*}{\multicolumn{2}{|c|}{$\begin{array}{c}\mathbf{3}^{\text {rd }} \\
\text { Confirmatory Test. }^{\text {Aids scan Rapid kit }} \\
\text { Test. }\end{array}$}} & \multicolumn{2}{|c|}{ Total (\%) } \\
\hline & \multicolumn{2}{|c|}{ Combs Test. } & \multirow[t]{2}{*}{ Total } & & & & & \multirow[t]{2}{*}{ Reactive } & \multirow[t]{2}{*}{$\begin{array}{c}\text { Non- } \\
\text { Reactive }\end{array}$} \\
\hline & Reactive & $\begin{array}{c}\text { Non- } \\
\text { Reactive }\end{array}$ & & Reactive & $\begin{array}{c}\text { Non } \\
\text { Reactive }\end{array}$ & Reactive & $\begin{array}{c}\text { Non- } \\
\text { Reactive }\end{array}$ & & \\
\hline 262 & 87 & 175 & 262 & 87 & 00 & 87 & 00 & $33 \%$ & $67 \%$ \\
\hline
\end{tabular}

Table- 4 Total HIV Reactive samples Fluorescence Microscopy result

\begin{tabular}{|l|c|c|c|c|}
\hline \multirow{2}{*}{$\begin{array}{l}\text { Total No of HIV } \\
\text { Reactive Samples. }\end{array}$} & \multicolumn{4}{|c|}{$\begin{array}{c}\text { Fluorescence Microscopy. } \\
\text { Total No of Sputum Positive samples. }\end{array}$} \\
\cline { 2 - 5 } & Positive. & Total (\%) & Negative. & Total (\%) \\
\hline 87. & 31 & $36 \%$ & 56 & $64 \%$ \\
\hline
\end{tabular}


Table-5 HIV/TB Co infected Patients Drug Sensitive Test with \%.

\begin{tabular}{|l|c|c|c|c|c|c|}
\hline \multirow{2}{*}{$\begin{array}{l}\text { Total Number Of } \\
\text { HIV/TB } \\
\text { Co infected Patients. }\end{array}$} & \multicolumn{6}{|c|}{ Drug Sensitive Test } \\
\cline { 2 - 7 } & $\begin{array}{c}\text { RGIT } \\
\text { ( Resistant) }\end{array}$ & $\begin{array}{c}\text { Total } \\
(\%)\end{array}$ & $\begin{array}{c}\text { Isoniazid. } \\
(\text { Resistant) }\end{array}$ & $\begin{array}{c}\text { Total } \\
(\%)\end{array}$ & $\begin{array}{c}\text { (Multi drug Resistant) } \\
\text { Rifampicin/Isoniazid }\end{array}$ & $\begin{array}{c}\text { Total } \\
(\%)\end{array}$ \\
\hline 31. & 06 & $19 \%$ & 04 & $12 \%$ & 3 & $9.6 \%$ \\
\hline
\end{tabular}

Table-6 Non HIV TB infected patients Drug Sensitive Test with \%.

\begin{tabular}{|c|c|c|c|c|c|c|}
\hline \multirow{2}{*}{$\begin{array}{l}\text { Total Number of } \\
\text { Non HIV TB } \\
\text { infected patients }\end{array}$} & \multicolumn{6}{|c|}{$\begin{array}{c}\text { Drug Sensitive Test } \\
\text { MGIT }\end{array}$} \\
\hline & $\begin{array}{c}\text { Rifampici } \\
\text { n }\end{array}$ & $\begin{array}{l}\text { Total } \\
(\%)\end{array}$ & Isoniazid & $\begin{array}{c}\text { Total } \\
(\%)\end{array}$ & $\begin{array}{c}\text { ( Multi drug Resistant) } \\
\text { Rifampicin/ Isoniazid }\end{array}$ & $\begin{array}{l}\text { Total } \\
(\%)\end{array}$ \\
\hline 175 & 25 & $14 \%$ & 16 & $9.1 \%$ & 4 & $2.2 \%$ \\
\hline
\end{tabular}

\section{Discussion}

This study shows the HIV /TB Co-infections is Major Health problems of worldwide. The HIV /TB Co-infected Patients suffering from Multi drug resistant tuberculosis because of HIV weakens the immune system of the body and increases the risk of TB with Multi drug resistant tuberculosis. ${ }^{\{\mathbf{1 3}, \mathbf{1 4}\}}$ That is caused by Mycobacterium Tuberculosis that are resistant to some of the most effective anti-TB drugs. In our study focus the HIV/TB co- infection \& multi drug resistant tuberculosis inthe coal field area of dhanbad District of Jharkhand. In This study all patients of both genders who were more than 18 years of age and Suspected of having HIV and Tuberculosis were included. Our study from blood and Sputum samples were divided into Males and Females sex groups according to their sex (According to Table Table 1). In This study total of 262 sputum samples were collected .There were $115(44 \%)$ sputum samples were positive and 147 $(56 \%)$ sputum samples were Negative. The total number of tuberculosis affecting Males 73 and female 42 (According to Table Table- 02), There were 87 blood Samples were reactive of HIV (Table-03). In This study 87 HIV reactive blood samples and 31 samples were HIV /TB coinfected. (According to Table Table-04) Total HIV /TB co-infected patients were 31 in our study of 06 samples were Rifampicin resistant and 04 samples were resistant to isoniazid and o3 samples were multi drug resistant. (According to Table Table 5).

\section{Conclusion}

In this study show that HIV/TB co-infected patients Rifampicin drug resistant and Multidrug resistant percentage much higher than for non HIV infected tuberculosis patients. In Our investigation we found that the isoniazid both resistant in HIV/TB co- infected patients and nonHIV tuberculosis patients but HIV/TB co- infected patients more higher resistant than nontuberculosis patients.

Declaration: This study is done with the name, address, and any other contacts of the Person will be kept secret. Duration of study: One Year.

Acknowledgments: This Research study is permitted by:

Institutional Ethics Committee, Patliputra Medical Collage, Dhanbad.

IEC PMCH Register by: (The Central Drugs Standard Control organization)

Director General of Health Services, Ministry of Health \&Family Welfare, government of India.

\section{References}

1. World Health Organization (2012). Global Tuberculosis report 2012.ISBN978-924156450-2.

2. World Health Organization (1999). Tuberculosis infection control in the era of expanding HIV care and treatment.

3. J. Bruchfeld, G. Aderaye, I.B Palme et.all 'Molecular epidemiology and drug 
resistance of Mycobacterium Tuberculosis isolates from Ethiopian pulmonary tuberculosis patients with and without immunodeficiency Virus infection." Journal of Clinical Microbiology. Vol.40,no5,pp.1636-1643,2002

4. M.demissi, E lemma, M, Gebeyehu, and B Lindtjorn "senstivity to anti- tuberculosis drugs in HIV positive and negative patients in Addis Ababa' Scandinavian journal of infection desease, vol, 33no-12.

5. D. Van Soolingen 'Molecular epidmology of tuberculosis and other mycobacterial infection: main methodologis and achivents " journal of internal medicine, vol.249,no.pp 1-26,2001

6. WHO," Global tuberculosis report 2012", Tech.rep World Health Organization Geneva Switzerland, 2012.

7. C.c Boehme, P Nabeta, D. Hillemann er all "Rapid molecular detection of tuberculosis and rifampicin resistance", New England journal of Medicine.

8. World Health organization (WHO).2013b. Definitions and reporting framework for tuberculosis-2013. World Health organization, Geneva.

9. Centers for Disease Control and Prevention .2013. Provisional CDC guideline for the use and safety monitoring of bedaquline fumrate for the treatment of Multidrug resistant tuberculosis. MMWR Rep: 62.

10. Ahuja SD, Ashink D, Avendan M, Banerjee Burgos M,Centies R, eral. 2012. Multidrug resistant pulmonary tuberculosis treatment regimens and patients out comes. An individual patient data Meta analysis of9, 513 patients Med 9: e1001300.
11. WHO, Global tuberculosis reports2015' Tech Rep...Molecular detection of tuberculosis and other mycobacterium infection main methodologies and achivents Journal of Internal Medcine, vol.249.no1, pp1-26, 2001.

12. M.Rifat, A.H.Milton, J Hall et al., in Bagladesh a casecontrol study on risk factors 'vol.2015 Article ID 215015, 10pages, 2015.

13. World Health Organization " tuberculosis infection control in the era of expanding HIV Care and treatment " tuberculosis and HIV January 2013.

14. Curry international Tuberculosis Centre, California Department of public Health 2012. Tuberculosis Drug information. 